WIDER Working Paper 2016/90

Imports, supply chains, and firm productivity

Carol Newman, ${ }^{1}$ John Rand, ${ }^{2}$ and Finn Tarp ${ }^{3}$

July 2016 
Abstract: This paper explores the relationship between imports and firm productivity, focusing on imported intermediates. Using firm-level data on over 20,000 manufacturing firms in Viet Nam, we find evidence for competition-induced productivity gains from trade. We show that gains in intermediate sectors spill-over to downstream sectors such that firms using more inputs from import-intensive sectors experience higher productivity gains. The evidence indicates that the main source of spill-over is better quality, domestically produced inputs. Ignoring the gains from trade through this mechanism may significantly underestimate the impact of trade on productivity.

Keywords: imports, supply chains, productivity, Viet Nam

JEL classification: F61, F63, F14, O12, O53

Acknowledgements: The authors are grateful for collaboration with staff at the Central Institute of Economic Management (CIEM) and the General Statistics Office (GSO) in Hanoi, Viet Nam. Our thanks to participants at various conferences and seminars where this paper was presented including Trinity College Dublin, the University of Copenhagen, the University of Nottingham, the Nordic Conference in Development Economics in Norway, the European Economics Association Conference in Gothenberg, the International Economics Association Conference in Jordon, and the Irish Economics Association Conference in Dublin. We have also benefitted from comments from Miklós Koren, Chris Udry, Fadi Hassan, and Gaia Narciso. The usual disclaimer applies.

\footnotetext{
${ }^{1}$ Department of Economics, Trinity College Dublin, Republic of Ireland, corresponding author: cnewman@tcd.ie; ${ }^{2}$ University of Copenhagen, Denmark; and ${ }^{3}$ UNU-WIDER, Helsinki, Finland and University of Copenhagen, Denmark.

This study has been prepared within the UNU-WIDER project on 'Structural Transformation and Inclusive Growth in Viet Nam'.

Copyright (C) UNU-WIDER 2016

Information and requests: publications@wider.unu.edu

ISSN 1798-7237 ISBN 978-92-9256-133-8
}

Typescript prepared by Lesley Ellen.

The United Nations University World Institute for Development Economics Research provides economic analysis and policy advice with the aim of promoting sustainable and equitable development. The Institute began operations in 1985 in Helsinki, Finland, as the first research and training centre of the United Nations University. Today it is a unique blend of think tank, research institute, and UN agency — providing a range of services from policy advice to governments as well as freely available original research.

The Institute is funded through income from an endowment fund with additional contributions to its work programme from Denmark, Finland, Sweden, and the United Kingdom.

Katajanokanlaituri 6 B, 00160 Helsinki, Finland

The views expressed in this paper are those of the author(s), and do not necessarily reflect the views of the Institute or the United Nations University, nor the programme/project donors. 
Trade liberalization in the developing world has attracted the interest of much academic research aimed at understanding the extent to which exposure to foreign competition impacts on industry and firm productivity and-by implication-aggregate economic growth. One under-explored mechanism is the impact that exposure to imported intermediates has on the productivity of firms, both directly (i.e. horizontally) on competing (same-sector) domestic firms, on the one hand, and through vertical (between-sector) supply chain linkages from upstream to downstream sectors, on the other. We aim to help fill this gap by investigating empirically the way in which imports of inputs influence the productivity of domestic firms in the context of Viet Nam.

Our analysis begins by considering the horizontal or within-sector effects whereby an expansion in imported inputs leads to an increase in competition for domestic input producers (see, for example, Holmes and Schmitz 2001; Amiti and Konings 2007). Exposure to competition will force the least efficient firms to exit or switch sector while survivors will cut slack or engage in innovations that reduce costs or distinguish them from imports. Reallocations from the least efficient to the most productive firms have long been predicted as an important source of productivity gains from trade (Melitz 2003). The overall impact will be an increase in the average efficiency level of domestic firms. We might also expect an improvement in the quality of domestically produced inputs if domestic firms learn from higher quality imported inputs or simply improve the quality of the goods they produce to compete with imports.

By inducing a reorganization of production, imports can lead to productivity improvements for all downstream firms, those that import intermediates, and those that rely on domestic upstream suppliers. The next step in our analysis therefore focuses on the impact of reorganization along the above lines on the productivity of downstream firms, i.e. through the supply chain. This effect has recently been recognized as a possible 'missing' gain from trade by Melitz and Redding (2014). They highlight the potential for trade to lead to endogenous changes in domestic productivity through gains that are realized at each intermediate stage of production. We rely on their theoretical framework and aim to empirically identify the extent to which productivity gains are realized through this channel.

Accordingly, we consider two mechanisms through which productivity gains can transmit through the supply chain: first, the extent to which downstream import firms benefit from technology spill-overs, variety, or quality effects associated with using higher quality imported inputs; and second, the extent to which downstream firms benefit from increased importinduced competition upstream leading to higher average efficiency levels among domestic input suppliers and better quality domestically produced inputs. In other words, we distinguish between the direct effects on firms that import intermediates and the indirect effects on firms that use domestically produced inputs.

The former is based on the idea that in a developing country context, imports from more advanced economies will be of a higher quality and embody more sophisticated technology than locally produced inputs. As such, an expansion of imported intermediates will lead to technology diffusion through greater variety, better quality inputs, and new technologies embodied in those inputs (Grossman and Helpman 1991; Halpern et al. 2015). Our point of departure is that we test whether firms that do not import inputs, but purchase them from domestic producers, experience a productivity gain as a result of import competition in intermediate goods sectors. If competition from imported intermediates leads to within-firm efficiency or productivity improvements that result in better quality domestically produced inputs, this may lead to 
productivity improvements in downstream sectors that purchase these inputs. This latter indirect effect has, to our knowledge, not been explored empirically so far. ${ }^{1}$

To be clear, we first examine the extent to which imports lead to within-sector competitioninduced productivity improvements and whether this, in turn, leads to forward spill-overs through the supply chain to downstream firms that use these inputs. To disentangle the direct and indirect effects on productivity we examine the differential effect of imports on importing compared with non-importing firms. The following three productivity-enhancing mechanisms are therefore in focus:

- Mechanism 1: Impact of expanded imports on domestic competitors—horizontal effects

- Mechanism 2: Impact on downstream firms, which import intermediates, from upstream sectors-vertical direct effects

- Mechanism 3: Impact on downstream firms, which do not import intermediates, from upstream sectors-vertical indirect effects

In addition, we explore some of the mechanisms underlying within-firm efficiency improvements in response to increased imports by considering effects on sector-level concentration, on the sector-level covariance between productivity and firm size, on the productivity of surviving firms, and the differential effect of imports from high-income compared with low-income countries. ${ }^{2}$

Our data includes an extensive firm-level panel dataset on over 20,000 private domestic manufacturing firms in Viet Nam for the period 2008 to 2013. We match the firm-level data to import and export statistics from COMTRADE at the 4-digit sector level. To measure vertical effects we use a measure of supply chain linkages that captures the extent of exposure of a sector to imports upstream using Supply-Use Tables (SUT). While this is a similar approach to that used to identify vertical technology transfers from foreign firms, it has rarely been applied in the present context (Javorcik 2004; Newman et al. 2015). ${ }^{3}$

Our identification strategy relies on the inclusion of a rich set of control variables in our empirical specification including firm, sector, and time fixed effects along with time-varying firmand sector-level controls. To correct for any remaining sources of endogeneity we use an instrumental variables approach where imports into a sector are instrumented using: (i) the lag of the total level of imports into other countries in the South East Asian region (excluding Viet $\mathrm{Nam}$ ); and (ii) the distance from the country of origin of imports into Viet Nam. We argue that the first measure will be correlated with imports into Viet Nam, given that it will capture general demand trends into the region, but will be orthogonal to the sector-specific shocks that impact

\footnotetext{
${ }^{1}$ It should be noted, that in both cases, the higher quality of the inputs may be reflected in the market price and so on net there may be no observed effect on the measured productivity of users of these inputs.

${ }^{2}$ We recognize that trade liberalization is likely to impact on productivity through the expansion in exports as well; productivity gains are also possible through improvements in within-firm efficiency induced by exposure to competitive pressures. Moreover, firms may incur a sunk cost of entry into export markets and so measured productivity improvements may take some time to materialize. We do not consider these mechanisms here. Instead, we control for the simultaneous impact of exposure to export markets through the inclusion of relevant control variables.

${ }^{3}$ While Blalock and Veloso (2007) also use input-output tables to measure supply chain linkages, they focus on backward linkages from downstream import firms to upstream domestic suppliers of inputs.
} 
on firm-level productivity and imports into Viet Nam and the second is a standard proxy for transport costs.

Our results show that the most important channel through which imports impact on productivity is competition. Of particular note is our finding that foreign competition-induced gains from trade spill-over to downstream sectors through the domestic supply chain. We find that all downstream firms experience productivity gains through this channel, not just those that import intermediates. We find suggestive evidence that this is due to quality improvements in the production of intermediate inputs that result from a reorganization of production among domestic input producers. Our findings indicate that ignoring the gains from trade through the supply chain may significantly underestimate the impact of trade on the productivity of domestic firms as predicted by Melitz and Redding (2014); the gains from trade may in fact be much larger than previous empirical studies have estimated.

The remainder of the paper is organized as follows. Section 2 provides a brief review of background literature, and our empirical approach is presented in Section 3. Section 4 introduces the datasets and describes the evolution of the manufacturing sector in Viet Nam over the period of analysis. Section 5 presents results, and Section 6 concludes.

\section{Background literature}

It is widely recognized in the literature that there are two main channels through which imported intermediates can affect productivity: a technology channel and a competition channel. ${ }^{4}$ It is equally clear that most of the empirical literature linking trade to firm productivity to date has focused on reallocation effects rather than effects through the supply chain. To illustrate, Tybout et al. (1991) and Pavcnik (2002) find evidence of productivity enhancing effects from increased trade exposure in Chile in the 1970s; and Pavcnik attributes part of the productivity improvement to competition from imports leading to both within-firm productivity improvements and reallocations of resources away from the least productive firms. Similarly, Eslava et al. (2004) and Fernandes (2007) show that trade, labour, and financial reforms in Columbia in the 1990s were associated with aggregate productivity improvements due to a more efficient allocation of resources.

Fernandes (2007) also links productivity gains under trade liberalization to increases in imported intermediates, as does Amiti and Konings (2007). They estimate that the productivity gains associated with tariff reductions in intermediate inputs in Indonesia are at least as high as the gains associated with lower output tariffs. Other evidence for imported inputs as a channel for trade-induced productivity growth is provided by Kasahara and Rodrigue (2008) and Halpern et al. (2015) for Chile and Hungary, respectively. The overall picture is, however, mixed. Van Biesebroeck (2003), for example, finds no evidence that productivity improvements in Columbia are due to the use of foreign inputs. Similarly, Muendler (2004) finds limited effects of foreign inputs on productivity in Brazil.

We have already highlighted that vertical (between-sector) effects (from upstream to downstream sectors) of imports, in particular imported intermediates, on productivity has received very little attention to date in the micro empirical literature. One notable exception is Blalock and Veloso (2007). They focused on backward linkages through the supply chain in investigating the impact

\footnotetext{
${ }^{4}$ See Syverson (2011) for an overview of the literature on the determinants of firm level productivity.
} 
of imports on the productivity growth of firms in Indonesia. ${ }^{5}$ Further support for exploring trade impacts through the supply chain is provided by Caliendo and Parro (2012), who explored the importance of input-output linkages in evaluating the trade and welfare effects of tariff reductions. They apply their model to identify the effects of NAFTA tariff reductions and find that both the trade and welfare effects of tariff reductions are significantly smaller if input-output linkages are ignored.

It is pertinent here to note as well that there is a large literature set in developing country contexts that examines the relationship between productivity and exporting. The evidence suggests that export firms have higher productivity levels. They generally make up a self-selected group that is, on average, more productive than other firms. In addition, firms learn by exporting or experience technological spill-overs from their experience in foreign markets. ${ }^{6}$

Turning finally to our country setting, a relevant and comprehensive background study is McCaig and Pavcnik (2013). They summarize the many policy initiatives that have been taken in Viet Nam over the past three decades since the Doi Moi reform process was initiated in 1986. The policy measures taken have included a wide range of reform measures related to trade liberalization and the promotion of foreign direct investment (FDI). The latter occurred through successive revisions to investment laws between the late 1980s and the mid-2000s, while trade liberalization took the form of the removal of export taxes and non-tariff barriers and the negotiation of a series of trade agreements with ASEAN, the US, and the EU ultimately leading to WTO accession in 2007 . $^{7}$

\section{$3 \quad$ Empirical approach}

The first step in our analysis requires that we estimate productivity for each firm in our sample. We use firm-level data to estimate a production function for each 2-digit manufacturing sector and use the estimated parameters to back out a firm-specific measure of productivity. Simultaneity between productivity shocks (observed by the firm but not by the econometrician) and input choices leads to bias in OLS estimates of the coefficients on these inputs in a standard production function. ${ }^{8}$

A common approach to estimating the production function parameters in the presence of such bias is to use a semi-parametric estimator which applies some structure to the underlying decision-making process of firms (for example, Olley and Pakes (1996), Levinsohn and Petrin (2003), and Ackerberg et al. (2006)). In this paper we use the Ackerberg et al. (2006) modification of the Olley and Pakes (1996) approach and estimate it using Wooldridge's (2009) estimator. It addresses issues around the identification of the parameters in the first stage of the OP model. Details are provided in Newman et al. (2015) and are summarized in the Appendix.

\footnotetext{
${ }^{5}$ They find evidence that importing is a source of technology transfer for upstream firms supplying import-intensive downstream sectors.

${ }^{6}$ See Roberts and Tybout (1997), Clerides et al. (1998), Bernard and Jensen (1999), Blalock and Gertler (2004), Van Biesebroeck (2005), Bigsten et al. (2006), Foster et al. (2008), AND Newman et al. (2016) for examples.

${ }^{7}$ For an overview of the reform to investment laws in Viet Nam between 1986 and 2000 see Jenkins (2006), while Abbott et al. (2009) contribute to the trade and development literature on Viet Nam.

${ }^{8}$ For example, higher productivity firms may decide to employ more workers which would lead to an upward bias in the coefficient on labour if productivity is not controlled for. Labour decisions could also be countercyclical, and the coefficient on capital might also be biased for similar reasons.
} 
The first mechanism we consider relates to horizontal effects (Mechanism 1). To explore this we test whether there is a positive relationship between firm-level productivity and (4-digit) sectorlevel imports. We regress the firm-level productivity measure estimated in the first step on sector-level imports along with a variety of firm and sector-specific control variables as in equation (1).

$$
T F P_{i j t}=\alpha_{i}+\delta_{1} \ln i m p_{j t}+\boldsymbol{\varphi} \mathbf{X}_{i j t}+\boldsymbol{\eta} \mathbf{Z}_{j t}+s_{j}+\tau_{t}+e_{i j t}
$$

where $\ln i m p_{j t}$ is the $\log$ value of imports into sector $j$ in year $t ; \mathbf{X}_{i j t}$ are time varying firm specific controls; $\mathbf{Z}_{j t}$ are time varying sector specific controls; $\alpha_{i}$ are firm fixed effects; $s_{j}$ are sector fixed effects ${ }^{9}$ and $\tau_{t}$ are time dummies.

Identification of the relationship between imports and productivity comes from the impact of the level of imports into the sector on the within-firm variation in productivity over time. ${ }^{10} \mathrm{In}$ other words, we identify the effects through considering how the productivity of firms varies in response to changes in 4-digit sector-level aggregates controlling for all time-invariant heterogeneity in firms and sectors. We include as well a variety of time-varying firm-specific and sector-specific control variables. Whether the firm is an import firm is key to our identification of the mechanisms, particularly in relation to supply chains.

The inclusion of time-varying sector-specific (4-digit) variables allows us to control for factors that may be correlated with firm productivity and with the level of imports into a sector. These include the average size of the sector in terms of the number of employees, the proportion of total revenue in the sector earned by foreign-owned firms, and the proportion of total revenue in the sector earned by state-owned firms, and we also control for the level of exports from the sector. In all specifications we control for sector-level concentration ratios. This is measured using the standard Herfindahl-Hirchman Index (HHI) given in equation (2).

$$
H H I_{j t}=\sum_{i=1}^{n} s_{i j t}^{2}
$$

where $s_{i j t}$ is the revenue share of firm $i$ in sector $j$ at time $t$.

Identifying causality is a challenge in this kind of model. Even with the inclusion of our controls there may still be unobserved sector-specific factors that impact on both the level of imports into a sector- and firm-level productivity. Controlling for time- and sector-specific effects goes some way to overcoming this problem. ${ }^{11}$ However, one potential source of omitted variable bias

\footnotetext{
${ }^{9}$ Due to the large amount of firms that switch sectors in Viet Nam both firm and sector specific fixed effects are required. See Newman et al. (2013) for a detailed analysis of sector switching.

${ }^{10}$ We also consider imports as a proportion of total output in a sector plus imports into that sector as an alternative measure of a sector's level of exposure to import competition. All of our results hold when using this measure. Results are available on request.

${ }^{11}$ Blalock and Veloso (2007) base their identification strategy on a similar approach, i.e. controlling for all timeinvariant heterogeneity across sectors.
} 
is time-varying sector-specific shocks, such as demand shocks, that impact on imports into a sector- and firm-level productivity. ${ }^{12}$

Another possible source of endogeneity is measurement error. Our main variable of interest is imports into a particular 4-digit sector, and our dependent variable is at the firm level. From a firm's perspective the import measure is an aggregation of imports into all sub-sectors that the 4digit sector encompasses, including those without direct relevance to the firm. This means that the import variable is measured with error, and this error will be embodied in the error term leading to bias in the OLS estimates.

To address potential endogeneity concerns we instrument for the level of imports into a sector using the lagged level of imports into that sector in the South East Asian region (excluding Viet Nam). ${ }^{13}$ The countries included are Brunei, Cambodia, Indonesia, Malaysia, Myanmar, Singapore, and Thailand. This measure will be correlated with the level of imports into that sector into Viet Nam as it will pick up the general trend in the demand for these goods in the region. Using total imports into the whole region eliminates the possibility that the instrument is contaminated by sector-specific shocks that impact on Viet Nam and other individual countries such as Cambodia or Thailand.

We also consider a second instrument which captures the average distance imports into Viet Nam travel to proxy transport costs. It is constructed by computing the distance between Viet Nam and the country of origin of imports into each 4-digit sector using the CEPII GeoDist database (Mayer and Zignago 2011). This database records the distance between capital cities. For each 4-digit sector we compute a weighted average of distances from markets where the weights are based on the proportion of imports into the sector that comes from that country in that year. As such the measure varies across time and 4-digit sectors. We expect distance travelled to be correlated with the level of imports into a given sector in a given year. Moreover, transport costs are exogenously given and if we assume that all markets respond in a similar way to a Viet Nam sector-specific shock, the instrument will not be related with this potential source of endogeneity.

Turning next to the vertical effects, we explore whether the impact of upstream imports are different for downstream import firms (Mechanism 2) and non-import firms (Mechanism 3). We use a similar specification to that presented in equation (1) as shown in equation (3).

$$
T F P_{i j t}=\alpha_{i}+\delta_{1} \ln i m p_{j t}+\delta_{2} \text { primpin }_{u j t}+\boldsymbol{\varphi} \mathbf{X}_{i j t}+\boldsymbol{\eta} \mathbf{Z}_{j t}+s_{j}+\tau_{t}+e_{i j t}
$$

where primpin $_{u j t}$ is the proportion of inputs into sector $j$ from upstream sector $u$, accounted for by imports. It is computed as described in equation (4).

\footnotetext{
${ }^{12}$ Reverse causality is unlikely. The productivity of an individual firm is not likely to impact the total level of imports into that sector. This would only be the case if a firm was particularly big or a sector was particularly concentrated, both of which we control for in the analysis. If reverse causality were a problem it would understate the coefficient on imports. In any case, our IV strategy will allow for this possibility.

13 Inspiration comes from Autor et al. (2013) who instrument for Chinese imports into the US using Chinese imports into other high income countries.
} 


$$
\operatorname{primpin}_{u j t}=\sum_{u=1}^{J-1} \omega_{u j}\left(\text { imp }_{u t} /\left(o u t_{u t}+\operatorname{imp}_{u t}\right)\right)
$$

where weights $\omega$ capture the proportion of total inputs into sector $j$ that comes from sector $u$, computed using an input-output table.

As an additional control we include a measure of the level of concentration in upstream sectors. This is computed using a weighted average of the HHI (computed as in equation (2)) as follows:

$$
H H I_{-} u p_{j t}=\sum_{u=1}^{J-1} \omega_{u j} H H I_{u t}
$$

where $\omega$ are weights as defined for equation (4). In concentrated sectors that have been shielded from competition, an expansion in imports is likely to have a bigger effect on overall efficiency levels than in competitive sectors where firms in general are likely to be already operating efficiently. An expansion in imports into concentrated sectors is in the first instance likely to lead firms to reduce mark-ups. Downstream firms will benefit from this in terms of a reduced price for their inputs. Given that our productivity measure is revenue based this will appear as a productivity improvement. Controlling for the extent of concentration upstream therefore allows us to better isolate the supply chain impact on downstream firms of import-induced efficiency gains (rather than changes in mark-ups).

Endogeneity concerns also arise when considering the relationship between the proportion of imports into upstream sectors and the productivity of downstream firms. It is likely that there are sector-specific shocks that will be correlated with the overall level of imports into upstream sectors and the productivity of firms in downstream sectors that are not controlled for in the empirical specification. To address this concern we instrument for the proportion of imports into upstream sectors using the change in the average level of imported inputs into upstream sectors in the South East Asian region (excluding Viet Nam). This is described in equation (6).

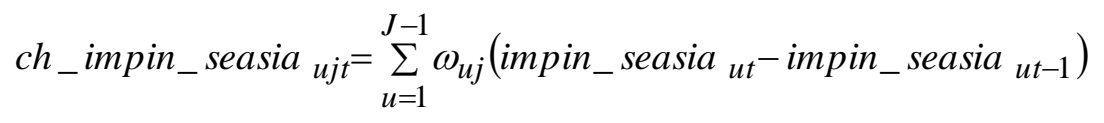

where the weights $\omega$ are as defined in equation (4) and impin_seasia $a_{u t}$ is the level of imports into upstream sector $u$ in the South East Asian region. While this measure will be correlated with the level of imports into upstream sectors in Viet Nam (and therefore the proportion of inputs provided by upstream sectors that are inputs), it is unlikely to be correlated with sector specific shocks that impact on the productivity of firms in downstream sectors in Viet Nam.

To examine the impact on importing firms we include an interaction term between whether the firm imports intermediates and primpin $_{u j t}$. This allows us to determine whether an expansion in imports into upstream sectors leads to productivity impacts for firms that import these intermediates specifically or impacts positively on the productivity of firms more generally. If imports induce competition and improve the efficiency of upstream firms through reorganizing production processes then this may spill-over to downstream firms (Melitz and Redding 2014). 
Our primary data source is the 2008-13 Enterprise Surveys collected annually by the General Statistics Office (GSO). This dataset includes the population of all registered enterprises with 30 employees or more and a representative sample of smaller firms. The focus of our analysis is on private domestic firms. The sample we use covers 49,147 observations from more than 20,000 private domestic manufacturing enterprises. ${ }^{14}$ Descriptive statistics of the main firm-specific variables of interest are presented in Table 1. The dynamic nature of the Vietnamese economy is evident. The average firm size in our sample declined from around 100 employees in 2008 to approximately 79 in 2011 and increased again to 112 in 2013. Between 6 and 14 per cent of firms exited each year; and the proportion of firms that imported increased from 13 to 20 per cent between 2008 and 2012. Likewise the proportion of firms that export doubled.

Import and export data are taken from the UN COMTRADE database available through World Integrated Trade Solutions on the value of exports and imports for 4-digit ISIC sectors for Viet Nam with the rest of the world. To measure supply chain linkages we use the Viet Nam SupplyUse Tables (SUT) for 2007. The SUT maps the use of 138 commodities in 112 production activities. We link these production activities to the 4-digit ISIC codes used in the Enterprise Survey to produce 42 comparable sector codes. The SUT data are used to construct a set of weights that captures upstream linkages between sectors, whereby for each (SUT) sector $i$, their link with upstream (SUT) sector $j$ is the proportional contribution of output from sector $j$ to its total input base. These weights are used to compute a weighted average of imports from upstream sectors where imports are measured as the proportion of total output in the sector produced in Viet Nam. ${ }^{15}$

Table 1: Private domestic manufacturing firms: descriptive statistics

\begin{tabular}{l|lllllll}
\hline & $\begin{array}{l}\text { Number } \\
\text { of firms }\end{array}$ & $\begin{array}{l}\text { Value } \\
\text { added } \\
\text { (million } \\
\text { VND) }\end{array}$ & $\begin{array}{l}\text { Size } \\
\text { (employees) }\end{array}$ & $\begin{array}{l}\text { Capital } \\
\text { (million } \\
\text { VND) }\end{array}$ & $\begin{array}{l}\text { Importer } \\
\text { (per cent) }\end{array}$ & $\begin{array}{l}\text { Exporter } \\
\text { (per cent) }\end{array}$ & $\begin{array}{l}\text { Exits } \\
\text { (per cent) }\end{array}$ \\
\hline 2008 & 6,417 & 1,604 & 101 & 10,609 & 13.4 & 9.6 & 7.3 \\
2009 & 7,447 & 1,799 & 94 & 11,618 & 11.7 & 9.8 & 7.6 \\
2010 & 9,879 & 1,643 & 80 & 10,912 & 10.9 & 11.8 & 14.3 \\
2011 & 9,856 & 1,655 & 79 & 11,084 & 20.1 & 13.6 & 6.8 \\
2012 & 8,162 & 1,676 & 83 & 11,590 & 20.8 & 14.3 & 6.4 \\
2013 & 7,386 & 2,609 & 112 & 16,512 & 18.8 & 19.2 & \\
\hline
\end{tabular}

Source: Authors' calculations based on Vietnamese Enterprise Surveys.

Table 2 presents the (average) extent of exposure of each 2-digit sector to imported inputs. ${ }^{16}$ The numbers presented can be interpreted as the proportion of imported inputs into the sector.

\footnotetext{
14 The full VES sample includes over 43,000 private domestic firms for the 2008-12 period. Using our approach to estimating productivity is quite demanding on the data in that it requires a number of lags and positive investment levels by firms. This leads to a reduced sample of approximately 17,000 firms. As a robustness check on our results we use the production function parameters estimated using the reduced sample to back out productivity for the full sample of firms. All of our results hold. We also use a one-stage approach to investigating the link between imports and productivity whereby value added is regressed on inputs, the horizontal and vertical import measures, and all of the other control variables discussed in Section 3. Our results hold using this approach.

${ }^{15}$ Calculated as imports into the sector/ (output produced domestically in the sector + imports into the sector).

${ }^{16}$ Viet Nam uses an industry classification code that is similar to ISIC Rev4. The list of sectors corresponding to each 2-digit code is provided in the Appendix.
} 
There is a lot of variation over time and across sectors. ${ }^{17}$ Of particular note is the decline in some of the later years. This reflects the combination of growth in domestically produced output over this time frame and the world financial crisis, which meant that more domestic output remained in-country.

Table 2: Exposure of downstream sectors to upstream imports (per cent)

\begin{tabular}{l|llllll}
\hline Sector & 2008 & 2009 & 2010 & 2011 & 2012 & 2013 \\
\hline 10 & 45.77 & 44.17 & 44.42 & 46.16 & 46.81 & 46.43 \\
11 & 48.10 & 43.39 & 44.08 & 43.99 & 42.86 & 42.77 \\
13 & 29.75 & 28.15 & 27.74 & 27.18 & 26.37 & 27.29 \\
14 & 7.82 & 7.32 & 8.47 & 7.76 & 7.94 & 7.97 \\
15 & 33.43 & 34.08 & 32.19 & 29.07 & 30.38 & 31.12 \\
16 & 61.27 & 59.62 & 51.06 & 45.18 & 43.52 & 43.70 \\
17 & 46.32 & 43.60 & 42.12 & 40.66 & 41.23 & 43.61 \\
18 & 16.01 & 15.45 & 13.05 & 10.58 & 9.51 & 8.38 \\
20 & 48.42 & 43.09 & 42.54 & 41.63 & 41.23 & 41.72 \\
21 & 51.18 & 46.76 & 47.51 & 50.63 & 52.27 & 53.12 \\
22 & 44.50 & 39.75 & 39.33 & 38.74 & 37.50 & 37.61 \\
23 & 54.69 & 47.85 & 47.98 & 47.03 & 45.89 & 45.82 \\
$24-25$ & 66.34 & 64.45 & 63.75 & 62.87 & 62.92 & 62.80 \\
26 & 38.85 & 37.04 & 36.96 & 36.89 & 38.19 & 37.22 \\
27 & 21.58 & 20.51 & 20.86 & 20.82 & 20.36 & 21.24 \\
28 & 30.31 & 26.72 & 26.563 & 25.95 & 25.49 & 25.80 \\
$29-30$ & 33.46 & 29.36 & 28.26 & 27.59 & 26.69 & 26.88 \\
31 & 0.32 & 0.30 & 0.29 & 0.28 & 0.28 & 0.29 \\
32 & 5.36 & 2.24 & 2.97 & 6.62 & 6.27 & 8.43 \\
\hline
\end{tabular}

Note: Exposure is defined as the share of imported input into sectors.

Source: Authors' calculations based on Vietnamese Enterprise Surveys.

We include a number of additional control variables in each econometric specification. We control for whether a firm is an import or an export firm and include sector-level controls for the concentration of foreign and state-owned firms in a sector, the size of the sector, and the level of exports from that sector.

\section{$5 \quad$ Results}

Production functions are estimated separately for each sub-sector of manufacturing. ${ }^{18}$ The coefficient estimates are presented in Table A2 of the Appendix alongside the estimates from OLS estimation. ${ }^{19}$ All of the estimated coefficients on the production function parameters leadas expected with OLS - to a biased estimation of productivity. ${ }^{20}$ The growth in productivity for each sub-sector for the $2008-13$ period is presented in Table A3 of the Appendix. ${ }^{21}$

\footnotetext{
${ }^{17}$ Sectors 24 and 25, and sectors 29 and 30 are aggregated so that they can be matched to the codes available in the SUT tables.

${ }^{18}$ Sectors are divided into 2-digit sub-sectors for the purpose of estimating productivity. Sector codes are defined in Table A1 of the Appendix.

${ }^{19}$ In determining the final specification of each production function we employ the usual tests for the validity of the instruments including weak identification, under-identification and first stage F-tests, all of which confirm the validity of the instruments. To test for over-identification we use higher order terms of the instruments or additional lags but for each sector, the final specification is an exactly identified system to avoid additional loss of data. The results are robust to different combinations of valid over-identifying restrictions.

${ }^{20}$ In all cases the coefficient on capital is lower when the production function is estimated using our preferred approach as compared with OLS. This suggests that firm capital choices are positively correlated with productivity
} 
To explore within-sector (horizontal) effects of imports on the productivity of domestic firms, we estimate equation (1). ${ }^{22}$ Results are presented in Table 3 . We find a positive and significant relationship between the level of imports and productivity (column 1). The null hypotheses that the model is under-identified and that the instruments are weak are both rejected and the test for over-identification fails to reject the null hypothesis that the instruments are valid. Using IV estimation (column 2) leads to an increase in the coefficient on imports from 0.082 to 0.515 . This is consistent with a downward bias in the OLS estimates due to an omitted sector-time specific variable correlated with both imports and firm productivity.

To interpret the import coefficient we give consideration to the fact that imports are included in $\log$ form. On the basis of our model, a one per cent increase in imports (which on average would equate to an increase of US $\$ 50$ million in value terms) will, ceteris paribus, increase productivity by 0.515 per cent. Considering that over the sample period average productivity grew by around 10 per cent this impact is economically meaningful.

In column (3) we check the robustness of our result to the inclusion of an interaction term between the level of imports into a sector and the level of concentration of that sector measured by the HHI. ${ }^{23}$ Given that our measure of productivity is revenue based, changes in productivity capture both real productivity changes and changes in mark-ups. In competitive sectors (i.e. those with a lower HHI) mark-ups will be lower and so any effect of an expansion in imports on productivity is likely to be explained by the former. The inclusion of the interaction term allows us to isolate the productivity impact of imports in competitive sectors. As revealed in column (3) we find that all of the impact is due to the expansion of imports into competitive sectors and so is likely due to real productivity effects.

leading to a bias in the capital coefficient when OLS is used. The coefficient on labour is also lower for some sectors when using our approach. This suggests that there is a positive correlation between labour and productivity in these sectors leading to an upward bias in the labour coefficient when using OLS. It is, however, higher in others, suggesting that in these sectors there is a negative correlation between labour and productivity. This is consistent with the idea that more productive firms employ fewer units of labour per unit of output.

${ }^{21}$ Average productivity levels across sectors cannot be compared given that the production functions are estimated separately for each sector. This means that we are assuming that firms within sectors share a common technology but that this technology is different between sectors. The productivity trajectory in each sector can be compared.

22 The domestic Vietnamese manufacturing sector is characterized by a high degree of sector switching by firms (Newman et al. 2013). The inclusion of sector-level fixed-effects controls for the possibility that the relationship between imports and productivity is being driven by firms moving between sectors.

${ }^{23}$ We instrument for the interaction between the log of imports and the HHI using the interaction between the instrument for the log of imports (i.e. the lag of imports into the South East Asian region) and the HHI as is standard practice. 
Table 3: Imports and the productivity of private domestic firms

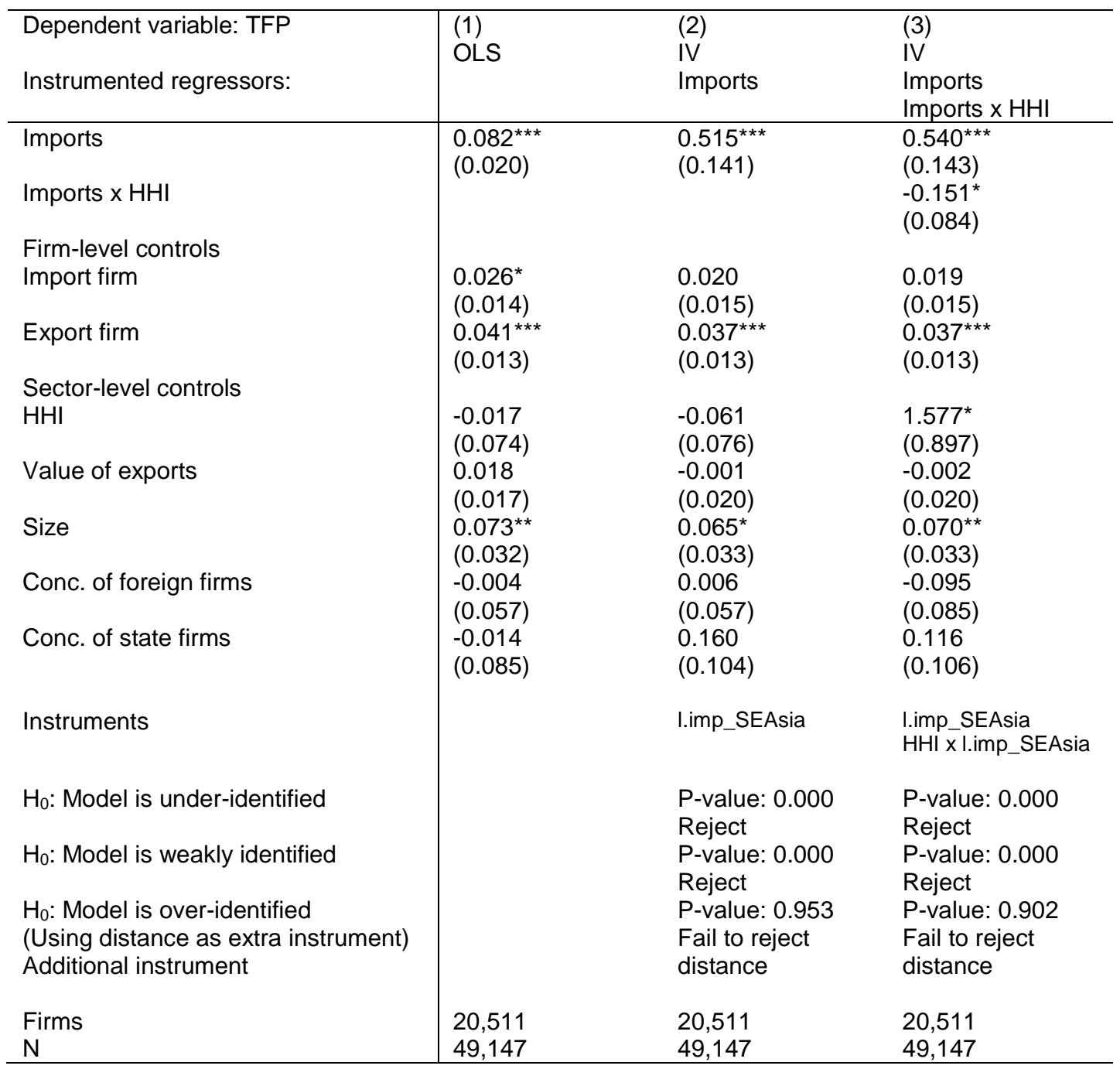

Note: Robust standard errors clustered at the firm level are presented in parenthesis. All results are robust to bootstrapping the standard errors. All models control for firm, year and 4-digit sector fixed effects to account for firms that switch between sectors. ${ }^{* \star *}$ indicates significance at the 1 per cent level, ${ }^{* *}$ the 5 per cent level, and * the 10 per cent level. The under-identification test is based on the Kleibergen-Paap rk LM statistic, the weak identification test is based on the Cragg-Donald Wald F statistic, test for endogeneity is based on the difference between the Sargan-Hansen statistics for the restricted and unrestricted models, and the test for the overidentifying restrictions is based on Hansen's $\mathrm{J}$ test.

Source: Authors' calculations based on Vietnamese Enterprise Surveys.

The next step in our analysis explores the extent to which imports impact on firms through the supply chain. We estimate the model given in equation (3). Results are presented in Table 4. We first estimate the model using OLS (column 1), which indicates that a one-percentage-point increase in the proportion of inputs into a sector that are imported is associated with a small increase in productivity of 0.012 per cent. 
Table 4: Imported inputs and the productivity of downstream private domestic firms

\begin{tabular}{|c|c|c|c|c|}
\hline $\begin{array}{l}\text { Dependent variable: TFP } \\
\text { Instrumented regressors: }\end{array}$ & $\begin{array}{l}\text { (1) } \\
\text { OLS }\end{array}$ & $\begin{array}{l}\text { (2) } \\
\text { IV } \\
\text { Imports } \\
\text { Upstream } \\
\text { imports }\end{array}$ & $\begin{array}{l}\text { (3) } \\
\text { IV } \\
\text { Imports } \\
\text { Upstream } \\
\text { imports } \\
\text { Upstream } \\
\text { imports x import } \\
\text { firm }\end{array}$ & $\begin{array}{l}\text { (4) } \\
\text { IV } \\
\text { Imports } \\
\text { Imports x HHI } \\
\text { Upstream } \\
\text { imports } \\
\text { Upstream } \\
\text { imports x import } \\
\text { firm }\end{array}$ \\
\hline $\begin{array}{l}\text { Imports } \\
\text { Imports } \times \mathrm{HHI}\end{array}$ & $\begin{array}{l}0.083^{\star \star \star} \\
(0.020)\end{array}$ & $\begin{array}{l}0.497^{\star \star \star} \\
(0.140)\end{array}$ & $\begin{array}{l}0.493^{\star \star \star} \\
(0.145)\end{array}$ & $\begin{array}{l}0.523^{\star \star \star} \\
(0.148) \\
-0.172^{\star *} \\
(0.085)\end{array}$ \\
\hline $\begin{array}{l}\text { Upstream imports } \\
\text { Upstream imports } x \text { import } \\
\text { firm }\end{array}$ & $\begin{array}{l}0.012^{* * *} \\
(0.002)\end{array}$ & $\begin{array}{l}0.029^{* * *} \\
(0.008)\end{array}$ & $\begin{array}{l}0.028^{\star \star \star} \\
(0.009) \\
-0.001 \\
(0.003)\end{array}$ & $\begin{array}{l}0.030 * * * \\
(0.009) \\
-0.001 \\
(0.003)\end{array}$ \\
\hline $\begin{array}{l}\text { Firm-level controls } \\
\text { Import firm }\end{array}$ & $\begin{array}{l}0.023 \\
(0.014)\end{array}$ & $\begin{array}{l}0.013 \\
(0.015)\end{array}$ & $\begin{array}{l}0.038 \\
(0.122)\end{array}$ & $\begin{array}{l}0.037 \\
(0.122)\end{array}$ \\
\hline $\begin{array}{l}\text { Export firm } \\
\text { Sector-level controls }\end{array}$ & $\begin{array}{l}0.041^{* \star \star} \\
(0.013)\end{array}$ & $\begin{array}{l}0.037^{\star \star \star} \\
(0.013)\end{array}$ & $\begin{array}{l}0.036^{\star \star \star} \\
(0.013)\end{array}$ & $\begin{array}{l}0.036^{* * *} \\
(0.013)\end{array}$ \\
\hline Upstream HHI & $\begin{array}{l}-0.049 \\
(0.074)\end{array}$ & $\begin{array}{l}-0.112 \\
(0.077)\end{array}$ & $\begin{array}{l}-0.111 \\
(0.077)\end{array}$ & $\begin{array}{l}1.745^{\star} \\
(0.903)\end{array}$ \\
\hline $\mathrm{HHI}$ & $\begin{array}{l}1.297^{\star \star \star} \\
(0.216)\end{array}$ & $\begin{array}{l}2.503^{\star \star \star} \\
(0.549)\end{array}$ & $\begin{array}{l}2.457^{\star \star \star} \\
(0.615)\end{array}$ & $\begin{array}{l}2.557^{\star \star *} \\
(0.623)\end{array}$ \\
\hline Value of exports & $\begin{array}{l}0.019 \\
(0.017)\end{array}$ & $\begin{array}{l}0.006 \\
(0.020)\end{array}$ & $\begin{array}{l}0.006 \\
(0.020)\end{array}$ & $\begin{array}{l}0.006 \\
(0.020)\end{array}$ \\
\hline Size & $\begin{array}{l}0.085^{\star \star *} \\
(0.032)\end{array}$ & $\begin{array}{l}0.083^{\star \star} \\
(0.033)\end{array}$ & $\begin{array}{l}0.084^{* *} \\
(0.033)\end{array}$ & $\begin{array}{l}0.090^{\star \star \star} \\
(0.033)\end{array}$ \\
\hline Conc. of foreign firms & $\begin{array}{l}0.019 \\
(0.057)\end{array}$ & $\begin{array}{l}0.051 \\
(0.059)\end{array}$ & $\begin{array}{l}0.049 \\
(0.059)\end{array}$ & $\begin{array}{l}-0.064 \\
(0.085)\end{array}$ \\
\hline Conc. of state firms & $\begin{array}{l}-0.064 \\
(0.085)\end{array}$ & $\begin{array}{l}0.063 \\
(0.100)\end{array}$ & $\begin{array}{l}0.060 \\
(0.102)\end{array}$ & $\begin{array}{l}0.008 \\
(0.104)\end{array}$ \\
\hline Instruments & & $\begin{array}{l}\text { I.imp_SEAsia } \\
\text { ch_upstream_i } \\
\text { mp_SEAsia }\end{array}$ & $\begin{array}{l}\text { I.imp_SEAsia } \\
\text { ch_upstream_i } \\
\text { mp_SEAsia } \\
\text { import firm x } \\
\text { ch_upstream_i } \\
\text { mp_SEAsia }\end{array}$ & $\begin{array}{l}\text { I.imp_SEAsia } \\
\text { ch_upstream_i } \\
\text { mp_SEAsia } \\
\text { import firm x } \\
\text { ch_upstream_i } \\
\text { mp_SEAsia } \\
\text { HHIx } \\
\text { I.imp_SEAsia }\end{array}$ \\
\hline $\mathrm{H}_{0}$ : Model is under-identified1 & & $\begin{array}{l}\text { P-value: } 0.000 \\
\text { Reject }\end{array}$ & $\begin{array}{l}\text { P-value: } 0.000 \\
\text { Reject }\end{array}$ & $\begin{array}{l}\text { P-value: } 0.000 \\
\text { Reject }\end{array}$ \\
\hline $\mathrm{H}_{0}$ : Model is weakly identified & & $\begin{array}{l}\text { P-value: } 0.000 \\
\text { Reject }\end{array}$ & $\begin{array}{l}\text { P-value: } 0.000 \\
\text { Reject }\end{array}$ & $\begin{array}{l}\text { P-value: } 0.000 \\
\text { Reject }\end{array}$ \\
\hline $\begin{array}{l}\mathrm{H}_{0} \text { : Model is over-identified } \\
\text { [Additional instrument] }\end{array}$ & & $\begin{array}{l}\text { P-value: } 0.512 \\
\text { Fail to reject } \\
\text { Distance }\end{array}$ & $\begin{array}{l}\text { P-value: } 0.533 \\
\text { Fail to reject } \\
\text { Distance }\end{array}$ & $\begin{array}{l}\text { P-value: } 0.476 \\
\text { Fail to reject } \\
\text { Distance }\end{array}$ \\
\hline $\begin{array}{l}\text { Firms } \\
\mathrm{N}\end{array}$ & $\begin{array}{l}20,511 \\
49,147\end{array}$ & $\begin{array}{l}20,511 \\
49,147\end{array}$ & $\begin{array}{l}20,511 \\
49,147\end{array}$ & $\begin{array}{l}20,511 \\
49,147\end{array}$ \\
\hline
\end{tabular}

Note: Robust standard errors clustered at the firm level are presented in parenthesis. All results are robust to bootstrapping the standard errors. All models control for firm, year and 4-digit sector fixed effects. ${ }^{* * *}$ indicates significance at the 1 per cent level, ${ }^{* *}$ the 5 per cent level, and * the 10 per cent level. All tests for validity of instruments hold and are available on request.

Source: Authors' calculations based on Vietnamese Enterprise Surveys. 
The proportion of inputs into upstream sectors may suffer from similar endogeneity problems as the level of imports into a sector. To correct for these we instrument (column 2) using the lag of the average level of imports into upstream sectors in the South East Asian region (excluding Viet $\mathrm{Nam}$ ) (see equation (6)). In this model the coefficient implies that a one-percentage-point increase in the proportion of imports into upstream sectors would lead to an increase in the level of productivity of 0.029 per cent. The horizontal effect of imports remains positive and statistically significant, although it is of a slightly lower magnitude than in the previous case. Thus, the effect on productivity we observe through the supply chain is an additional gain from trade; we highlight that this finding is consistent with Melitz and Redding's (2014) predictions.

To disentangle the extent to which the vertical effect is driven by improvements in productivity for firms that import intermediates we include an interaction term between the proportion of imports into upstream sectors and the indicator variable for whether a firm imports intermediates. We do not have a direct measure in our data of the level of intermediates that a firm imports. The interaction term will, however, allow us to determine whether the productivity impact on downstream firms is different for firms that directly import intermediates compared with those that do not. This will give us some indication as to whether the impact is a direct (Mechanism 2) or an indirect (Mechanism 3) effect.

The results are presented in column (3) of Table 4. We find no evidence to suggest that the impact of imports into upstream sectors is different for import firms compared with non-import firms. This means that the effect we observe appears through efficiency gains associated with Mechanism 3, i.e. productivity gains due to competition from imports in upstream sectors that are transmitted through the supply chain. We note that our indicator for importing firms does not take account of firms that import inputs through trade intermediaries. As such, we are careful not to conclude that there is no direct (Mechanism 2) productivity gain associated with importing inputs as found in other contexts. In column (4) we check the robustness of our results to the inclusion of an interaction between the value of imports and the HHI. All of our results hold.

In the final steps of our analysis we provide supporting evidence for our proposed mechanism. We first consider whether an expansion of imports into a sector is associated with a lower level of concentration indicating that there are indeed competitive pressures induced by imports. We estimate a regression model at the 4-digit sector level which relates the 4-digit concentration ratio described in equation (2) to the level of imports into the sector. We control for the range of time-varying sector-level variables included in the models presented in Tables 3 and 4, and a set of year and sector dummies. Results are presented in column (1) of Table 5. They show a negative relationship between the level of imports into a sector and the level of concentration suggesting that there is indeed a positive relation between the value of imports into a sector and the level of competition in that sector.

Second, to check for evidence of import-induced reallocations of resources from less productive to more productive firms, we estimate the within-sector covariance between productivity and firm size. This measure, originally proposed by Olley and Pakes (1996), has recently been used by Bartelsman et al. (2013) to examine the extent of misallocation of resources within industries across countries. A higher covariance indicates that resources are allocated more efficiently within a sector since the firms contributing the most to output are the most productive. For each 4-digit sub-sector we compute the covariance between the labour productivity of firms and the 
contribution of each firm to total output of the sector. ${ }^{24}$ We estimate a regression model at the 4digit sector level, where we examine the relationship between imports and the covariance term including the same set of time-varying sector-level variables, year and sector dummies, as is included in column (1). The results are presented in column (2) of Table 5. We find a positive and well-determined relationship between the level of imports into a sector and the covariance between productivity and firm size in that sector. This provides some evidence that imports are associated with a more efficient allocation of resources within sectors.

Third, we examine the effect of imports into a sector on the productivity of survivors, i.e. domestic firms that stay in the same sector during 2008-13. We re-estimate the model given in equation (1) for the reduced sample of domestic firms that do not exit the panel. Results are presented in column (3) of Table 5. We find a positive and well-determined relationship between the expansion of imports into a sector and the level of productivity of survivors in that sector. This provides further evidence that productivity-enhancing reallocations in response to imports is the mechanism through which imports impact on productivity.

As our fourth mechanism check, we consider whether the origin of imports matters. We separate out imports from high-income and low-income countries, ${ }^{25}$ assuming that the former are of higher quality. We restrict the sample to non-import firms and control for the overall level of imports into a sector. The results are presented in column (4). We find that the effect of upstream competition in imported inputs on the productivity of downstream domestic firms comes through imports from high-income countries. This suggests that there are quality effects on domestic input producers that spill-over to non-importing downstream firms.

\footnotetext{
${ }^{24}$ We use a partial productivity measure rather than our main TFP measure since the latter can only be aggregated to broadly defined sectors limiting the number of observations that can be included in the analysis. The correlations are similar when we use the latter although does not have enough power to determine statistical significance.

${ }^{25}$ We use the World Bank's list of the 80 high-income countries in the world.
} 
Table 5: Imports and productivity: mechanisms

\begin{tabular}{|c|c|c|c|c|}
\hline Dependent variable: & $\begin{array}{l}(1) \\
\text { OLS } \\
\text { HHI } \\
\text { Sectors }\end{array}$ & $\begin{array}{l}(2) \\
\text { OLS } \\
\text { Covariance } \\
\text { Sectors }\end{array}$ & $\begin{array}{l}\text { (2) } \\
\text { IV } \\
\text { TFP } \\
\text { Survivors }\end{array}$ & $\begin{array}{l}\text { (3) } \\
\text { IV } \\
\text { TFP } \\
\text { Non- } \\
\text { importers }\end{array}$ \\
\hline $\begin{array}{l}\text { Log value of imports } \\
\text { Upstream imports - high income } \\
\text { Upstream imports - high income }\end{array}$ & $\begin{array}{l}-0.013^{\star \star} \\
(0.006)\end{array}$ & $\begin{array}{l}0.095^{\star \star \star} \\
(0.028)\end{array}$ & $\begin{array}{l}0.440^{\star \star \star} \\
(0.143)\end{array}$ & $\begin{array}{l}0.028 \\
(0.121) \\
0.109^{\star \star \star} \\
(0.040) \\
-0.020 \\
(0.038)\end{array}$ \\
\hline Firm fixed effects & No & No & Yes & Yes \\
\hline $\begin{array}{l}\text { Number of firms } \\
N\end{array}$ & 565 & 447 & $\begin{array}{l}16,918 \\
43,162 \\
\end{array}$ & $\begin{array}{l}19,067 \\
41,272 \\
\end{array}$ \\
\hline
\end{tabular}

Note: Robust standard errors are presented in parenthesis. Columns (1) and (2) include year and 2-digit sector fixed effects and standard errors are clusters at the 2-digit sector level. Columns (3) and (4) include year and 4digit sector fixed effects with standard errors clustered at the firm level. Columns (1) and (2) include all timevarying sector-level controls and columns (3) and (4) include all time-varying firm and sector-level controls. All results are robust to bootstrapping the standard errors. ${ }^{* * *}$ indicates significance at the 1 per cent level, ${ }^{* *}$ the 5 per cent level, and * the 10 per cent level. The instrument for the value of imports is the lag of imports into the South East Asian region in columns (3) and (4). In column (3) the proportion of imports from high- and lowincome countries into upstream sectors are instrumented using the change and lag level of imports into the South East Asian region into these sectors from high- and low-income countries, respectively. All tests for the validity of the instruments hold (results are available on request).

Source: Authors' calculations based on Vietnamese Enterprise Surveys.

\section{Conclusion}

This study explored the relationship between imports and the productivity of private domestic firms with the aim of disentangling three mechanisms through which productivity gains may be realized. Accordingly, we investigated both within-sector or horizontal effects, and betweensector or vertical effects of imports through the supply chain. We used firm-level enterprise data from Viet Nam for the 2008 to 2013 period. They were matched with trade data from COMTRADE for the same period, and input-output data were used to measure supply chain linkages.

We found strong evidence that imports impact on the productivity of domestic firms, both on competitors and on firms in downstream sectors through the supply chain. In contrast, no evidence emerged that domestic firms importing inputs experience additional productivity spillovers, though we were careful not to exclude this possibility. We found, however, that competition from imports is an important channel through which productivity gains are realized, and this is driven by reallocations of resources toward more productive firms.

Importantly, our results show that there are spill-over effects of the productivity gains experienced by upstream domestic firms for downstream firms that use these inputs. These spillovers are of a large magnitude although they are smaller than the competition effects themselves. We found some evidence to suggest that the effect is coming through competition from imports from high-income countries suggesting that the spill-over effects may be driven by quality improvements.

In sum, our empirical results highlight that previous empirical studies may have underestimated the productivity gains from trade. We believe this supports with novel empirical evidence the 
theoretical case made by Melitz and Redding (2014), and it certainly suggests that this line of research should attract attention in both further empirical work and in practical policy-making.

\section{References}

Abbott, P., J. Bentzen, and F. Tarp (2009). 'Trade and Development: Lessons from Vietnam's Past Trade Agreements'. World Development, (37)2: 341-53.

Ackerberg, D.A., K. Caves, and G. Frazer (2006). 'Structural Identification of Production Functions'. Mimeo, UCLA Department of Economics.

Amiti, M., and J. Konings (2007). 'Trade Liberalization, Intermediate Inputs and Productivity: Evidence from Indonesia'. American Economic Review, 97(5): 1611-38.

Autor, D.H., D. Dorn, and G.H. Hanson (2013). 'The China Syndrome: Local Labor Market Effects of Import Competition in the United States'. American Economic Review, 103(6): 212168.

Bartelsman, E., J. Haltiwanger, and S. Scarpetta (2013). 'Cross-country Differences in Productivity: The Role of Allocation and Selection'. American Economic Review, 103(1): 30534.

Bernard, A., and J. Jensen (1999). 'Exceptional Exporter Performance: Cause, Effect or Both?'. Journal of International Economics, 47(1): 1-25.

Bigsten, A., P. Collier, S. Dercon, M. Fafchamps, B. Gauthier, J.W. Gunning, A. Oduro, R. Oostendorp, C. Pattillo, M. Soderbom, F. Teal, and A. Zeufack (2006). 'Do African Manufacturing Firms Learn from Exporting??. Journal of Development Studies, 40(3): 115-41.

Blalock, G., and P. Gertler (2004). 'Learning from Exporting Revisited in a Less Developed Setting'. Journal of Development Economics, 75: 397-416.

Blalock, G., and F. Veloso (2007). 'Imports, Productivity Growth, and Supply Chain Learning'. World Development, 35(7): 1134-51.

Caliendo, L., and F. Parro (2012). 'Estimates of the Trade and Welfare Effects of NAFTA'. NBER Working Paper 18508. Cambridge, MA: National Bureau of Economic Research.

Clerides, S.K., S. Loch, and J.R. Tybout (1998). 'Is Learning by Exporting Important? Microdynamic Evidence from Columbia, Mexico and Morocco'. Quarterly Journal of Economics, 113(3): 903-47.

Eslava, M., J. Haltiwanger, A. Kugler, and M. Kugler (2004). 'The Effects of Structural Reforms on Productivity and Profitability Enhancing Reallocation: Evidence from Columbia'. Journal of Development Economics, 75: 333-71.

Fernandes, A. (2007). 'Trade Policy, Trade Volumes and Plant-level Productivity in Columbian Manufacturing Industries'. Journal of International Economics, 71: 52-71.

Foster, L., J. Haltiwanger, and C. Syverson (2008). 'Reallocation, Firm Turnover, and Efficiency: Selection on Productivity or Profitability?'. American Economic Review, 98(1): 394-425.

Grossman, G., and E. Helpman (1991). Innovation and Growth in the Global Economy. Cambridge, MA: MIT Press.

Halpern, L., M. Koren, and A. Szeidl (2015). 'Imports and Productivity'. American Economic Review, 105(12): 3360-703. 
Holmes, T., and J. Schmitz (2001). 'A Gain from Trade: From Unproductive to Productive Activities'. Journal of Monetary Economics, 47: 417-46.

Javorcik, B.S. (2004). 'Does Foreign Direct Investment Increase the Productivity of Domestic Firms? In Search of Spillovers Through Backward Linkages'. American Economic Review, (June): 605-32.

Jenkins, R. (2006). 'Globalization, FDI and Employment in Viet Nam'. Transnational Corporations, 15(1): 115-42.

Kasahara, H., and J. Rodrigue (2008). 'Does the Use of Imported Intermediates Increase Productivity? Plant-level Evidence'. Journal of Development Economics, 87: 106-18.

Levinsohn, J., and A. Petrin, (2003). 'Estimating Production Functions Using Inputs to Control for Unobservables'. Review of Economic Studies, 70: 317-41.

Mayer, T., and S. Zignago (2011). 'Notes on CEPII's Distances Measures: The GeoDist Database'. CEPII Working Paper 2011-25. Paris: CEPII.

McCaig, B., and N. Pavcnik (2013). 'Moving out of Agriculture: Structural Change in Vietnam'. NBER Working Paper No. 19616. Cambridge, MA: National Bureau of Economic Research.

Melitz, M.J. (2003). 'The Impact of Trade on Intra-industry Reallocations and Aggregate Industry Productivity'. Econometrica, 71(6): 1695-1725.

Melitz, M.J., and S.J. Redding (2014). 'Missing Gains from Trade?'. American Economic Review: Papers and Proceedings 2014, 104(5): 317-21.

Muendler, M. (2004). 'Trade, Technology and Productivity: A Study of Brazilian Manufacturers, 1986-1998'. Mimeo, UCSD.

Newman, C., J. Rand, and F. Tarp (2013). 'Industry Switching in Developing Countries'. World Bank Economic Review, 27(2): 357-88.

Newman, C., J. Rand, T. Talbot, and F. Tarp (2015). 'Technology Transfers, Foreign Investment and Productivity Spillovers'. European Economic Review, (76): 168-187.

Newman, C., J. Rand, F. Tarp, and T. Anh (2016). 'Exporting and Productivity: Learning from Viet Nam'. Journal of African Economies, Forthcoming.

Olley, G., and A. Pakes (1996). 'The Dynamics of Productivity in the Telecommunications Equipment Industry'. Econometrica, 64(6): 1263-97.

Pavcnik, N. (2002). 'Trade Liberalization, Exit, and Productivity Improvements: Evidence from Chilean Plants'. Review of Economic Studies, 69: 245-76.

Syverson, C. (2011). 'What Determines Productivity?'. Journal of Economic Literature, 49(2): 326-65.

Roberts, M., and J. Tybout (1997). 'The Decision to Export in Colombia: An Empirical Model of Entry with Sunk Costs'. American Economic Review, 87: 545-64.

Tybout, J., J. de Melo, and V. Corbo (1991). 'The Effects of Trade Reforms on Scale and Technical Efficiency: New Evidence from Chile'. Journal of International Economics, 31(3-4): 557-86.

Van Biesebroeck, J. (2003). 'Revisiting Some Productivity Debates'. NBER Working Paper 10065. Cambridge, MA: National Bureau of Economic Research.

Van Biesebroeck, J. (2005). 'Exporting Raises Productivity in Sub-Saharan African Manufacturing Firms'. Journal of International Economics, 67: 373-91. 
Wooldridge, J.M. (2009). 'On Estimating Firm-level Production Functions Using Proxy Variables to Control for Unobservables'. Economics Letters, 104: 112-14. 


\section{Appendix}

\section{Productivity Estimation}

We assume a Cobb-Douglas production function written in the following form for the purpose of empirical estimation:

$$
y_{i t}=\beta_{l} l_{i t}+\beta_{k} k_{i t}+\omega_{i t}+e_{i t}
$$

where $y_{i t}$ is the $\log$ of value added, ${ }{ }_{i t}$ is the log of the labour input, ${ }{ }_{i t}$ is the log of the capital input, $\omega_{i t}$ is unobserved productivity, and $e_{i t}$ is an unanticipated shock or random error term. As in OP we assume that productivity evolves according to a first-order Markov process so:

$$
E\left(\omega_{i t} \mid \omega_{i t-1}, \omega_{i t-2}, \ldots, \omega_{i 1}\right)=E\left(\omega_{i t} \mid I_{i t-1}\right)=E\left(\omega_{i t} \mid \omega_{i t-1}\right) \quad t=2,3, \ldots . . T
$$

where $I_{i t-1}$ is the information set at time $t-1$ and all past realizations of productivity are assumed to be part of that information set. In other words, the firm expectations about future productivity depend only on the productivity in the previous period.

We assume that investment, and hence the capital stock $k_{i t}$, is chosen at time $t-1$. This is consistent with the OP assumption about capital accumulation where capital is formed according to the following process:

$$
k_{i t}=(1-\delta) k_{i t-1}+i_{i t-1}
$$

where $i_{i t-1}$ is the lag of investment.

Also in accordance with OP, we assume that labour is chosen at the same time that productivity is realized. An implication of these assumptions regarding the timing of input choices and the evolution of productivity is that:

$$
\omega_{i t}=f\left(k_{i t}, i_{i t}\right)
$$

Assuming that $E\left(e_{i t} \mid k_{i t}, i_{i t}\right)=0$, and substituting for $\omega_{i t}$, the production function in equation (A1) can be written as:

$$
y_{i t}=\beta_{l} l_{i t}+\beta_{k} k_{i t}+f\left(k_{i t}, i_{i t}\right)+e_{i t} \quad t=1,2, \ldots ., T
$$

The parameters $\beta_{l}$ and $\beta_{k}$ will not be separately identified, the former due to collinearity between labour and productivity (Ackerberg et al. 2006) and the latter due to the inclusion of $k_{i t}$ in $f($.$) .$

Returning to the process assumed to underlie the evolution of productivity described in equation (A2) we define innovation as follows: 


$$
\xi_{i t}=\omega_{i t}-E\left(\omega_{i t} \mid \omega_{i t-1}\right)
$$

Combined with equation (4) which implies that $\omega_{i t-1}=g\left(k_{i-1}, i_{i t-1}\right)$ and after some rearranging, equation (A6) can be rewritten as:

$$
\omega_{i t}=f\left[g\left(k_{i-1}, i_{i t-1}\right)\right]+\xi_{i t}
$$

Substituting into equation (A1) provides us with a second equation which can be used to identify the two parameters of interest, ${ }^{\beta_{l}}$ and $\beta_{k}$ :

$$
y_{i t}=\beta_{l} l_{i t}+\beta_{k} k_{i t}+f\left[g\left(k_{i t-1}, i_{i t-1}\right)\right]+v_{i t}, t=2,3, \ldots ., T
$$

where $v_{i t}=\xi_{i t}+e_{i t}$. A set of suitable moment restrictions emerges from the assumptions underlying the evolution of productivity and the timing of the choice of inputs. Equation (A6) implies that innovation will be independent of the information set at time $t-1$, i.e. ${ }^{\omega_{i t-1}}$. Since $k_{i t}$ is determined at period $t-1$ it will be uncorrelated with unobserved innovation ${ }_{i t}$. In other words:

$$
E\left(\xi_{i t} \mid k_{i t}\right)=0
$$

Innovation will be correlated with any production decisions that are made between period $t-1$ and $t$. As such, the labour input, determined at period $t$, will be correlated with ${ }^{\xi_{i t}}$. This is not so for the lag of labour, ${ }{ }_{i t-1}$, since it is part of the information set at time $t-1$. As such:

$$
E\left(\xi_{i t} \mid l_{i t-1}\right)=0
$$

The full set of moment conditions for (8) is therefore given by $E\left(v_{i t} \mid k_{i t}, l_{i t-1}, k_{i t-1}, i_{i t-1}\right)=0$. The unknown functions $f($.$) and g($.$) are approximated by third-degree polynomials. Equation (8)$ can be estimated using pooled instrumental variables estimation with the instrument set $z_{i t}=\left(k_{i t}, l_{i t-1}, k_{i t-1}, i_{i t-1}, \ldots\right)$, where all higher-order terms and their interactions in the polynomials act as their own instruments and all lags can also be used as instruments in testing overidentifying restrictions. ${ }^{26}$ In the estimation of equation (A8) a full set of time dummies is included to control for heterogeneity over time in the production function and productivity. Once we have consistent estimators for $\beta_{l}$ and $\beta_{k}$, productivity can be estimated using equation (A11).

$$
\hat{\omega}_{i t}=y_{i t}-\hat{\beta}_{l} l_{i t}-\hat{\beta}_{k} k_{i t}
$$

\footnotetext{
${ }^{26}$ Alternatively, equations (5) and (8) can be estimated simultaneously using system GMM with instrument sets given by $z_{i t 1}=\left(l_{i t}, k_{i t}, i_{i t}, \ldots\right)$ and $z_{i t 2}=\left(k_{i t}, l_{i t-1}, k_{i t-1}, i_{i t-1}, \ldots\right)$, respectively.
} 
Table A1: 2-digit Sector Codes

\author{
10: Manufacture of food products \\ 11: Manufacture of beverages \\ 13: Manufacture of textiles \\ 14: Manufacture of wearing apparel \\ 15: Manufacture of leather and related products \\ 16: Manufacture of wood and products of wood and cork \\ 17: Manufacture of paper and paper products \\ 18: Printing and reproduction of recorded media \\ 20: Manufacture of chemicals and chemical products \\ 21: Manufacture of pharmaceuticals, medicinal chemical, and botanical products \\ 22: Manufacture of rubber and plastics products \\ 23: Manufacture of other non-metallic mineral products \\ 24: Manufacture of basic metals \\ 25: Manufacture of fabricated metal products, except machinery, and equipment \\ 26: Manufacture of computer, electronic, and optical products \\ 27: Manufacture of electrical equipment \\ 28: Manufacture of machinery and equipment not elsewhere classified \\ 29: Manufacture of motor vehicles, trailers, and semi-trailers \\ 30: Manufacture of other transport equipment \\ 32: Other manufacturing \\ 31: Manufacture of furniture
}

Source: Authors' illustration. 
Table A2: Production function estimates

\begin{tabular}{|c|c|c|c|c|c|}
\hline & Wooldridge & OLS & & Wooldridge & OLS \\
\hline VSIC 10-11 & & & VSIC 16 & & \\
\hline I & $\begin{array}{l}0.710^{\star * \star} \\
(0.018)\end{array}$ & $\begin{array}{l}0.776^{\star * \star} \\
(0.012)\end{array}$ & I & $\begin{array}{l}0.902^{* * *} \\
(0.021)\end{array}$ & $\begin{array}{l}0.891^{\star * *} \\
(0.016)\end{array}$ \\
\hline k & $\begin{array}{l}0.271^{\star * *} \\
(0.018)\end{array}$ & $\begin{array}{l}0.401^{* * *} \\
(0.007)\end{array}$ & k & $\begin{array}{l}0.253^{* * *} \\
(0.022)\end{array}$ & $\begin{array}{l}0.327^{* * *} \\
(0.009)\end{array}$ \\
\hline Instrument for I & lag_^^2 & & & lag_I & \\
\hline Observations & $12, \overline{7} 81$ & 12,781 & Observations & $5,7 \overline{8} 2$ & 5,782 \\
\hline RTS & 0.981 & 1.177 & RTS & 1.155 & 1.218 \\
\hline Under-ident. & 0.000 & & Under ident. & 0.000 & \\
\hline Weak ident. & 0.000 & & Weak ident. & 0.000 & \\
\hline $\begin{array}{l}\text { F-test of exl. } \\
\text { inst. }\end{array}$ & 0.000 & & $\begin{array}{l}\text { F-test of exl. } \\
\text { inst. }\end{array}$ & 0.000 & \\
\hline $\begin{array}{l}\text { Hansen J } \\
\text { statistic }\end{array}$ & 0.143 & & $\begin{array}{l}\text { Hansen J } \\
\text { statistic }\end{array}$ & 0.308 & \\
\hline Extra instrument & lag2_I & & $\begin{array}{l}\text { Extra } \\
\text { instrument }\end{array}$ & lag2_I & \\
\hline VSIC 13 & & & VSIC 17 & & \\
\hline I & $\begin{array}{l}0.843^{\star * *} \\
(0.022)\end{array}$ & $\begin{array}{l}0.835^{\star * *} \\
(0.019)\end{array}$ & 1 & $\begin{array}{l}1.062^{* * *} \\
(0.033)\end{array}$ & $\begin{array}{l}1.001^{* * *} \\
(0.025)\end{array}$ \\
\hline 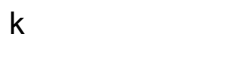 & $\begin{array}{l}0.221^{* * *} \\
(0.029)\end{array}$ & $\begin{array}{l}0.343^{* * *} \\
(0.011)\end{array}$ & k & $\begin{array}{l}0.081^{* *} \\
(0.035)\end{array}$ & $\begin{array}{l}0.268^{* * *} \\
(0.014)\end{array}$ \\
\hline Instrument for I & lag_I & & & lag_I & \\
\hline Observations & 3,436 & 3,436 & Observations & 3,489 & 3,489 \\
\hline RTS & 1.064 & 1.178 & RTS & 1.142 & 1.269 \\
\hline Under-ident. & 0.000 & & Under ident. & 0.000 & \\
\hline Weak ident. & 0.000 & & Weak ident. & 0.000 & \\
\hline $\begin{array}{l}\text { F-test of exl. } \\
\text { inst. }\end{array}$ & 0.000 & & $\begin{array}{l}\text { F-test of exl. } \\
\text { inst. }\end{array}$ & 0.000 & \\
\hline $\begin{array}{l}\text { Hansen J } \\
\text { statistic }\end{array}$ & 0.212 & & $\begin{array}{l}\text { Hansen J } \\
\text { statistic }\end{array}$ & 0.130 & \\
\hline Extra instrument & lag_|^2 & & $\begin{array}{l}\text { Extra } \\
\text { instrument }\end{array}$ & lag_|^2 & \\
\hline VSIC 14 & & & VSIC 18 & & \\
\hline I & $\begin{array}{l}1.011^{* * *} \\
(0.015)\end{array}$ & $\begin{array}{l}0.914^{\star * *} \\
(0.013)\end{array}$ & 1 & $\begin{array}{l}0.880^{* * *} \\
(0.031)\end{array}$ & $\begin{array}{l}0.789^{* * *} \\
(0.021)\end{array}$ \\
\hline 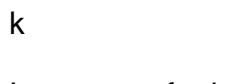 & $\begin{array}{l}0.087^{* * *} \\
(0.024)\end{array}$ & $\begin{array}{l}0.285^{* * *} \\
(0.010)\end{array}$ & $\mathrm{k}$ & $\begin{array}{l}0.205^{\star * *} \\
(0.025)\end{array}$ & $\begin{array}{l}0.413^{* * *} \\
(0.012)\end{array}$ \\
\hline Instrument for I & lag_I & & & lag_I & \\
\hline Observations & 4,957 & 4,957 & Observations & 2,647 & 2,647 \\
\hline RTS & 1.098 & 1.199 & RTS & 1.085 & 1.202 \\
\hline Under-ident. & 0.000 & & Under ident. & 0.000 & \\
\hline Weak ident. & 0.000 & & Weak ident. & 0.000 & \\
\hline $\begin{array}{l}\text { F-test of exl. } \\
\text { inst. }\end{array}$ & 0.000 & & $\begin{array}{l}\text { F-test of exl. } \\
\text { inst. }\end{array}$ & 0.000 & \\
\hline $\begin{array}{l}\text { Hansen J } \\
\text { statistic }\end{array}$ & 0.429 & & $\begin{array}{l}\text { Hansen } \mathrm{J} \\
\text { statistic }\end{array}$ & 0.327 & \\
\hline Extra instrument & lag2_I & & $\begin{array}{l}\text { Extra } \\
\text { instrument }\end{array}$ & lag_|^2 & \\
\hline VSIC 15 & & & VSIC 20-21 & & \\
\hline 1 & $\begin{array}{l}0.926^{\star * \star} \\
(0.026)\end{array}$ & $\begin{array}{l}0.856^{* * *} \\
(0.021)\end{array}$ & 1 & $\begin{array}{l}0.661^{* * *} \\
(0.037)\end{array}$ & $\begin{array}{l}0.738^{* * *} \\
(0.031)\end{array}$ \\
\hline 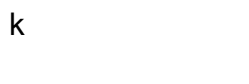 & $\begin{array}{l}0.132^{\star \star} \\
(0.043)\end{array}$ & $\begin{array}{l}0.306^{* * *} \\
(0.015)\end{array}$ & $\mathrm{k}$ & $\begin{array}{l}0.450^{\star * *} \\
(0.043)\end{array}$ & $\begin{array}{l}0.467^{* * *} \\
(0.015)\end{array}$ \\
\hline Instrument for I & lag_I & & & lag_I & \\
\hline Observations & $1,7 \overline{9} 0$ & 1,790 & Observations & $3,4 \overline{5} 3$ & 3,453 \\
\hline RTS & 1.058 & 1.162 & RTS & 1.111 & 1.205 \\
\hline Under-ident. & 0.000 & & Under ident. & 0.000 & \\
\hline Weak ident. & 0.000 & & Weak ident. & 0.000 & \\
\hline $\begin{array}{l}\text { F-test of exl. } \\
\text { inst. }\end{array}$ & 0.000 & & $\begin{array}{l}\text { F-test of exl. } \\
\text { inst. }\end{array}$ & 0.000 & \\
\hline $\begin{array}{l}\text { Hansen J } \\
\text { statistic }\end{array}$ & 0.743 & & $\begin{array}{l}\text { Hansen } \mathrm{J} \\
\text { statistic }\end{array}$ & 0.128 & \\
\hline Extra instrument & lag2_I & & $\begin{array}{l}\text { Extra } \\
\text { instrument }\end{array}$ & lag_|^3 & \\
\hline
\end{tabular}


Table A2 (continued): Production function estimates

\begin{tabular}{|c|c|c|c|c|c|}
\hline & Wooldridge & OLS & & $\begin{array}{l}\text { Wooldridg } \\
\mathrm{e}\end{array}$ & OLS \\
\hline VSIC 22 & & & VSIC 26-28 & & \\
\hline 1 & $\begin{array}{l}0.855^{\star \star \star} \\
(0.025)\end{array}$ & $\begin{array}{l}0.819^{\star \star \star} \\
(0.019)\end{array}$ & 1 & $\begin{array}{l}0.749^{\star * \star} \\
(0.028)\end{array}$ & $\begin{array}{l}0.766^{\star \star \star} \\
(0.021)\end{array}$ \\
\hline $\mathrm{k}$ & $\begin{array}{l}0.267^{\star * *} \\
(0.028) \\
\text { lag_I }\end{array}$ & $\begin{array}{l}0.370^{* * *} \\
(0.011)\end{array}$ & $\mathrm{K}$ & $\begin{array}{l}0.349^{* * *} \\
(0.031) \\
\text { lag_ı2 }\end{array}$ & $\begin{array}{l}0.411^{* * *} \\
(0.012)\end{array}$ \\
\hline Observations & $5,1 \overline{7} 5$ & 5,175 & Observations & 4,303 & 4,303 \\
\hline RTS & 1.122 & 1.189 & RTS & 1.098 & 1.177 \\
\hline Under-ident. & 0.000 & & Under ident. & 0.000 & \\
\hline Weak ident. & 0.000 & & Weak ident. & 0.000 & \\
\hline $\begin{array}{l}\text { F-test of exl. } \\
\text { inst. }\end{array}$ & 0.000 & & $\begin{array}{l}\text { F-test of exl. } \\
\text { inst. }\end{array}$ & 0.000 & \\
\hline $\begin{array}{l}\text { Hansen J } \\
\text { statistic }\end{array}$ & 0.132 & & $\begin{array}{l}\text { Hansen } \mathrm{J} \\
\text { statistic }\end{array}$ & 0.574 & \\
\hline Extra instrument & $\left.\operatorname{lag}\right|^{\wedge} 2$ & & Extra instrument & lag2_I & \\
\hline VSIC 23 & & & VSIC 29, 30, 32 & & \\
\hline I & $\begin{array}{l}0.839^{* * *} \\
(0.029)\end{array}$ & $\begin{array}{l}0.854^{* * *} \\
(0.020)\end{array}$ & I & $\begin{array}{l}0.761^{* * *} \\
(0.031)\end{array}$ & $\begin{array}{l}0.828^{* * *} \\
(0.024)\end{array}$ \\
\hline $\mathrm{k}$ & $\begin{array}{l}0.236^{\star * *} \\
(0.029) \\
\operatorname{lag}^{\wedge}{ }^{\wedge} 3\end{array}$ & $\begin{array}{l}0.352^{* \star \star} \\
(0.011)\end{array}$ & k & $\begin{array}{l}0.347^{\star \star \star} \\
(0.037) \\
\text { lag_ı3 }\end{array}$ & $\begin{array}{l}0.379^{* * *} \\
(0.014)\end{array}$ \\
\hline Observations & 5,962 & 5,962 & Observations & 3,055 & 3,055 \\
\hline RTS & 1.075 & 1.206 & RTS & 1.108 & 1.207 \\
\hline Under-ident. & 0.000 & & Under ident. & 0.000 & \\
\hline Weak ident. & 0.000 & & Weak ident. & 0.000 & \\
\hline $\begin{array}{l}\text { F-test of exl. } \\
\text { inst. }\end{array}$ & 0.000 & & $\begin{array}{l}\text { F-test of exl. } \\
\text { inst. }\end{array}$ & 0.000 & \\
\hline $\begin{array}{l}\text { Hansen J } \\
\text { statistic }\end{array}$ & 0.269 & & $\begin{array}{l}\text { Hansen J } \\
\text { statistic }\end{array}$ & 0.680 & \\
\hline Extra instrument & lag2_I & & Extra instrument & lag2_I & \\
\hline VSIC 24-25 & & & VSIC 31 & & \\
\hline I & $\begin{array}{l}0.835^{\star \star *} \\
(0.022)\end{array}$ & $\begin{array}{l}0.847^{\star * *} \\
(0.014)\end{array}$ & I & $\begin{array}{l}1.015^{\star \star \star} \\
(0.023)\end{array}$ & $\begin{array}{l}0.862^{\star \star \star} \\
(0.016)\end{array}$ \\
\hline 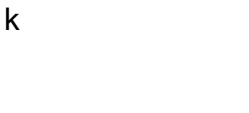 & $\begin{array}{l}0.201^{\star \star *} \\
(0.016) \\
\operatorname{lag}^{\wedge} 2\end{array}$ & $\begin{array}{l}0.363^{* \star *} \\
(0.008)\end{array}$ & k & $\begin{array}{l}0.137^{\star \star \star} \\
(0.027) \\
\text { lag_l }\end{array}$ & $\begin{array}{l}0.320^{\star * *} \\
(0.010)\end{array}$ \\
\hline Observations & $11, \overline{0} 28$ & 11,028 & Observations & 4,928 & 4,928 \\
\hline RTS & 1.036 & 1.210 & RTS & 1.152 & 1.182 \\
\hline Under-ident. & 0.000 & & Under ident. & 0.000 & \\
\hline Weak ident. & 0.000 & & Weak ident. & 0.000 & \\
\hline $\begin{array}{l}\text { F-test of exl. } \\
\text { inst. }\end{array}$ & 0.000 & & $\begin{array}{l}\text { F-test of exl. } \\
\text { inst. }\end{array}$ & 0.000 & \\
\hline $\begin{array}{l}\text { Hansen J } \\
\text { statistic }\end{array}$ & 0.148 & & $\begin{array}{l}\text { Hansen } \mathrm{J} \\
\text { statistic }\end{array}$ & 0.719 & \\
\hline Extra instrument & lag2_I & & Extra instrument & $\left.\operatorname{lag}\right|^{\wedge} 2$ & \\
\hline
\end{tabular}

Note: Robust standard errors are presented in parenthesis. ${ }^{* * *}$ indicates significance at the 1 per cent level, ${ }^{* *}$ the 5 per cent level, and * the 10 per cent level. P-values for under-identification test is based on the KleibergenPaap rk LM statistic, weak identification test is based on the Cragg-Donald Wald F statistic, F-test is based on Angrist-Pischke multivariate F-test of excluded instruments in the first stage, and the test for the over-identifying restrictions is based on Hansen's $\mathrm{J}$ test. Sectors 21-22, 30-33, and 34-35 are combined in estimating productivity due to small number of observations in some sectors. The implication of this is that they are assumed to have common production functions.

Source: Authors' calculations based on Vietnamese Enterprise Surveys. 
Table A3: Estimated average productivity and productivity growth 2008-13

\begin{tabular}{lllllll}
\hline 2-digit sector & 2008 & 2009 & 2010 & 2011 & 2012 & 2013 \\
\hline $10-11$ & 100.0 & 112.3 & 109.8 & 104.8 & 108.2 & 110.7 \\
13 & 100.0 & 114.2 & 128.3 & 122.3 & 132.4 & 135.8 \\
14 & 100.0 & 105.1 & 116.3 & 115.5 & 112.5 & 118.6 \\
15 & 100.0 & 98.1 & 116.2 & 111.5 & 116.7 & 118.1 \\
16 & 100.0 & 127.3 & 112.8 & 114.6 & 109.5 & 112.7 \\
17 & 100.0 & 107.1 & 116.7 & 111.2 & 115.5 & 115.7 \\
18 & 100.0 & 112.3 & 111.9 & 95.9 & 99.2 & 98.9 \\
$20-21$ & 100.0 & 118.9 & 131.7 & 105.8 & 119.0 & 137.8 \\
22 & 100.0 & 116.0 & 124.9 & 122.7 & 150.2 & 143.4 \\
23 & 100.0 & 108.9 & 102.7 & 96.2 & 84.6 & 88.2 \\
$24-25$ & 100.0 & 104.4 & 108.8 & 98.4 & 100.5 & 104.1 \\
$26-28$ & 100.0 & 114.6 & 119.5 & 109.6 & 115.9 & 119.9 \\
$29,30,32$ & 100.0 & 99.3 & 107.7 & 103.6 & 109.8 & 120.1 \\
32 & 100.0 & 118.0 & 126.3 & 112.9 & 121.3 & 127.1 \\
\hline
\end{tabular}

Source: Authors' calculations based on Vietnamese Enterprise Surveys. 